\title{
The efficacy of clove (Eugenia caryophyllata) powder as anaesthesia on African catfishes (Clarias gariepinus and Heterobranchus bidorsalis) fingerlings
}

\begin{abstract}
The efficacy of clove powder as anaesthetic agent on C. gariepinus and Heterobranchus bidorsalis fingerlings was investigated in this study and the water quality parameters of the test solutions also determined. The time of induction and recovery for various stages and concentrations was recorded in minutes using a stop watch. The concentrations used for the anaesthesia bioassay were $60,70,80,100,120$, and $140 \mathrm{mg} / 1$. The water quality parameters examined after 30 mins did not differ $(\mathrm{P}<0.05)$ from those of control hence may not have contributed to the observed behaviour of the test fish. Fingerlings exposed to 60 and $70 \mathrm{mg} / 1$ had partial anaesthesia and did not achieved stage 4(deep anaesthesia) after 30mins. Those exposed to concentration above $70 \mathrm{mg} / 1$ were completely immobilized (deep anaesthesia) within $3-10$ mins depending on concentration. The mean time under each concentration increased significantly $(\mathrm{P}<0.05)$ from stages $1-4$. The various stages of induction and recovery of $C$. gariepinus were higher than those of $H$. bidorsalis except induction stages 1 and 3 and recovery stage 3 . Increasing concentration proportionally decrease the induction time but increase the time required for full recovery. An ideal anaesthetic must have among other qualities quick induction and slightly longer recovery time to allow for varied manipulation as desirable. In this study clove powder at 120 and $140 \mathrm{mg} / \mathrm{l}$ induced deep anaesthesia in less than 5 mins with a recovery time of $25-27$ mins, making it an ideal anaesthestic for African clarrid fingerlings.
\end{abstract}

Keywords: clove powder, african catfishes, fingerlings, induction, recovery

\section{Introduction}

Aquaculture practices frequently exposed fish to a variety of acute stressor that have the potential to negatively affect the normal performance and survival of organism. ${ }^{1,2}$ Anaesthetic abolishes pain in fish and induces a calming effect, loss of equilibrium, mobility and consciousness. ${ }^{3,4}$ In fisheries research and aquacultural operations, anaesthetics are necessary to minimize stress and reduce physical injury of fish during various handling procedures and transportation..$^{5,6}$ Anaesthetics have also been reported to minimize mortality and reduce susceptibility to pathogens and infections. ${ }^{7}$ Anaesthetics most commonly used by commercial fish culturist and biologist include metomidate, tricaine methane sulphonate (MS 222), etomidate, benzocaine- hydrochloride, phenoxyethanol and eugenol. ${ }^{8-10}$ Some plant extract such as Derris (rotenone), tephrosia (tephrosin), Erythrophleum (alkaloid and tanin), Pyrus (tannin and saponin) and Tobacco (nicotine) have also been reported to have anaesthetic effects on fish. ${ }^{11-13}$ Clove oil derived from clove plant Eugenia caryophyllata (4- allyl-methoxylphenol) is regarded as the best anaesthetics to various fishes. ${ }^{14,15}$

The desirable attributes of anaesthetics used for fin fish include, short induction and recovery time, non-toxicity to fish and humans, no lasting physiological effects, rapid clearance from the body, high solubility in fresh and salt water, availability and cost effectiveness. ${ }^{8,16}$ Sudagara et al., ${ }^{16}$ stated that although clove oil is adjudged the best anaesthtics for aquaculture organism but not readily soluble in water, not easily available and costly. To solve this problem, biologists and aquaculturists have been searching for alternative anaesthetics that apart from been less toxic, efficacious and safe for humans, should be readily available and cheap. ${ }^{17,18}$
Volume 7 Issue 4 - 2018

\author{
Okey IB,' Keremah RI,' Gabriel UU \\ 'Department of Fisheries and Aquatic Science, Cross River \\ University of Technology, Nigeria \\ ${ }^{2}$ Department of Fisheries/ Livestock Production Technology, \\ Niger Delta University, Nigeria \\ ${ }^{3}$ Department of Fisheries and aquatic environment, Rivers State \\ University of Science and Technology, Nigeria
}

Correspondence: Okey IB, Department of Fisheries and Aquatic Science, Cross River University of Technology, Obubra Campus, Cross River State, Nigeria, Email piusbass@yahoo.com

Received: May 06, 2018 | Published: July 03, 2018
Clove powder is derived from the dry flower buds and stalks of clove plant E. caryophyllata. The efficacy of this powder has been evaluated on common Iranian fish Roach, Rutilus rutilus. ${ }^{16}$ Clove powder is readily available, highly soluble in water and cheap. In Nigeria clove products are sold in most herbal shops and markets use primarily for flavouring food (spice) and supplement for topical treatment of tooth ache, common cold, cough and inflammation of the mouth and throat. ${ }^{19}$ In cross river, clove flower buds are commonly known as "zobo" spice sold in most markets across the state.

The African catfishes, Clarias gariepinus and Heterobranchus bidorsalis constitute the largest group of cultured species after carp, salmonids and tilapia, and they grow well under various culture systems of the world. ${ }^{20}$ Their culture is becoming more popular among fish farmers in Cross River, where they are being transported from hatcheries sites to grow out ponds research labouratories. According to Sudagara et al., ${ }^{16}$ clove powder is highly soluble in water, cheap and effective anaesthetic to Roach with reversible damage to damage to bloodstream. Similar observation was reported by Okey et al., ${ }^{21}$ for hybrid catfish on clove powder. The aim of the study is the determine the efficacy and effective concentration of clove powder on the two species of African catfishes $C$. gariepinus and H. bidorsalis fingerlings.

\section{Materials and methods}

Dry E. caryophyllata flower buds were procured from a herbal shop in watt market Calabar, Calabar South Local Government Area of Cross River State, Nigeria. The materials were identified at the Department of Botany University of Calabar (UNICAL). They were taken to the Fisheries Laboratory Cross River University of Technology (CRUTECH,) Obubra Campus. The flower buds were sundried for 30 
min and then pulverized with a sterile manual blender and sieved with 100 micron net to obtain a fine powder. The powder was put in an airtight container and stored in a dry place prior to commencement of the experiment. Two hundred each of apparently healthy fingerlings of C. gariepinus $(3.26 \mathrm{~g} \pm 2.30 \mathrm{SD} ; 8.34 \mathrm{~cm} \pm 1.82 \mathrm{SD})$ and $H$. bidorsalis $(2.89 \mathrm{~g} \pm 1.80 \mathrm{SD} ; 7.55 \mathrm{~cm} \pm 1.04 \mathrm{SD})$ were procured from UNICAL fish Farm, Calabar and acclimated for 14 days at the Fisheries Wet Labouratory, Cross River University of Technology (CRUTECH) Obubra, Nigeria. No mortality was recorded during the period of acclimation and feeding was discontinued 12 hours before and during the experiment to minimize contamination of the test medium. A stock solution of clove power with a concentration of $200 \mathrm{mg} / \mathrm{L}$ was prepared by dissolved $2 \mathrm{~g}$ of clove powder into $10 \mathrm{~L}$ of borehole water. Exposure concentrations of clove powder were 60, 70, 80, 100, 120 and $140 \mathrm{mg} / 1$, respectively. Thirty six glass aquaria were clean and randomly labeled and each filled with water to the 15 litres mark for induction test and 20L mark for recovery. The different concentrations were prepared by serial dilution of the stock solution and water added to make up to $20 \mathrm{~L}$ that gave the desired test concentrations. The mixture was stirred with a glass rod for homogenous mixing. Each concentration was stock with 10 fingerlings each in triplicate and monitored for the onset of induction (anaesthesia) for $30 \mathrm{~min}$ as periods greater than this were considered not ideal and impractical for routine fish handling procedures. ${ }^{14,22}$ The test fish were monitored following the various stages of induction and recovery time using a stop watch (Table 1). Any of the test fish that lost balance and ceased respiratory movements of the opercula (deep anaesthesia, stage 4) was removed immediately and transferred to about $20 \mathrm{~L}$ of clove powder free water. The time for the fish to enter the desirable anaesthesia level (induction) and that which is required for an anesthetized fish to regain equilibrium and began active swimming (recovery time) were recorded at each stage.

Table I Stages of anaesthesia (Induction) and recovery

\begin{tabular}{llll}
\hline Stages & $\begin{array}{l}\text { Anaesthesia(induction) } \\
\text { Behavior of the fish }\end{array}$ & Stages & $\begin{array}{l}\text { Recovery } \\
\text { Behavior of the fish }\end{array}$ \\
\hline I & $\begin{array}{l}\text { Acceleration of the opercular movements, increased respiratory } \\
\text { activity, accompanied by uncoordinated locomotion. }\end{array}$ & I & $\begin{array}{l}\text { Body immobilized but opercular movements just } \\
\text { starting and weak, uncoordinated locomotion }\end{array}$ \\
II & $\begin{array}{l}\text { Sporadic loss of equilibrium, difficulty maintaining position while at } \\
\text { rest, high reaction to external stimuli. }\end{array}$ & II & $\begin{array}{l}\text { Regular opercular movements and gross body } \\
\text { movements beginning. }\end{array}$ \\
III & Complete loss of equilibrium; inability to regain upright position. & III & $\begin{array}{l}\text { Equilibrium regained, normal swimming and pre- } \\
\text { anaesthetic appearance. }\end{array}$ \\
IV & No reaction to handling or a sharp prod in the peduncle. & n
\end{tabular}

Source: Iwama et al., ${ }^{23}$

During the study, the following water quality parameters were monitored in the experimental and control tanks: temperature, $\mathrm{pH}$ dissolved oxygen, alkalinity, conductivity and hardness. The water temperature was measured using the mercury in glass thermometer and recorded in ${ }^{\circ} \mathrm{C}$. Conductivity was with conductivity meter (PACM 35 Model) and $\mathrm{pH}$ meter (Model 3015 Jenway) for $\mathrm{pH}$. Dissolved oxygen was measured with a digital oxygen meter. Alkalinity was determined by standard method. ${ }^{24}$ Total hardness was determined by ethylene diamine- tetra acetic acid (EDTA) titration method. Data obtain from the various stages of induction (anaesthesia) and recovery time were subjected to various statistical tools. Descriptive statistic was used to obtain the means and standard error (Mean \pm S.E). Differences among mean time for different dosage to achieve various stages of anesthesia and recovery time on concentration were subjected to one way ANOVA using SPSS 18.0 version. Differences in means were separated using Tukey-Honest Significant Different (T-HSD) test and F-test for significant level at $(\mathrm{p}<0.05)$ between the treatments. ${ }^{25,26}$

\section{Results}

\section{Water quality parameters}

The result of the water quality parameters as shown in Table 2 indicates that their mean values did not differ $(p>0.05)$ from those of the control. The mean values of the various parameters decreased with increasing concentrations as follows, temperature $\left(28.13-26.88^{\circ} \mathrm{C}\right)$, dissolved oxygen $(4.74-4.12 \mathrm{mg} / 1), \mathrm{pH}(6.78-6.77)$ and hardness (39.32-38.80mg/l $\left.\quad \mathrm{CaCO}_{3}\right)$. Conductivity $(166.07-167.05 \mu \mathrm{Scm} / 1)$ and alkalinity $(37-41-38.51 \mathrm{mg} / \mathrm{l})$ had a slight increase above those of control at $140 \mathrm{mg} / \mathrm{l}$ of clove powder after $30 \mathrm{mins}$ of exposure.

\section{Induction and recovery of $C$. gariepinus and $\boldsymbol{H}$. bidorsalis fingerling from clove powder anaesthetic}

The $C$. gariepinus fingerlings exposed to concentrations below $80 \mathrm{mg} / \mathrm{l}$ did not reach stage 4 (complete immobilization) but with partial loss of equilibrium (stages 1-3) in 6-13mins. At $80 \mathrm{mg} / 1, C$. gariepinus fingerlings lost equilibrium in 6-9 mins and completely immobilized in 12 mins and begins recovery in 7-9mins. At 120 and $140 \mathrm{mg} / 1$ fish were completely anaesthetized (stage 4) within 2-5mins and regained equilibrium between $10-27 \mathrm{mins}$. No mortality resulted from anaesthesia within $60-120 \mathrm{mg} / 1$ of clove powder after 30 mins of exposure. The mean induction time under each concentration increased significantly $(\mathrm{P}<0.05)$ from stages $1-4$. At the highest concentration $(140 \mathrm{mg} / 1)$, the induction stages were not significant $(\mathrm{P}>0.05)$ except at stage 4 (Table 3 ). The ANOVA indicated that powder caused significant changes $((\mathrm{P}<0.001)$ on all the stages of induction and recovery.

The anaesthesia and recovery time of $H$. bidorsalis from clove powder were similar to those of $C$. gariepinus fingerlings in which increasing concentrations of clove powder proportionally decreased the time required for induction. No complete immobilization was achieved between $60-70 \mathrm{mg} / 1$ of the anaesthetic. The time required to attained partial anaesthesia at stage 3 (19.00 and 10.00mins) was 
significantly higher than that of stage 2(10.88 and 7.73) for 60 and $70 \mathrm{mg} / \mathrm{l}$ respectively. At $120-140 \mathrm{mg} / \mathrm{l}$, the time to achieved complete immobilization was 4.93 and $2.33 \mathrm{mins}$ and completely regained equilibrium in 16.80 and $25.20 \mathrm{mins}$ respectively. At $140 \mathrm{mg} / 1$ stages induction stages 1 and 2 were not observed and the time to achieved stages $3(1.20 \mathrm{~min})$ and $4(2.33 \mathrm{~min})$ were not significant $(\mathrm{P}<0.05)$. The recovering time at stages 3 was higher $(\mathrm{p}<0.05)$ than those of stages 1 and 2 (Table 4). The ANOVA showed that clove caused highly significant $(\mathrm{P}<0.001)$ on the stages of induction and recovery.

Table 2 Water Quality Parameters in Experimental Tanks of African catfishes fingerlings exposed to clove powder for 30 mins

\begin{tabular}{|c|c|c|c|c|c|c|}
\hline \multirow{2}{*}{$\begin{array}{l}\text { Conc. } \\
(\mathrm{mg} / \mathrm{l})\end{array}$} & \multicolumn{6}{|l|}{ Parameter } \\
\hline & $\begin{array}{l}\text { Dissolved Oxygen } \\
(\mathrm{mg} / \mathrm{l})\end{array}$ & $\begin{array}{l}\text { Temperature } \\
\left({ }^{\circ} \mathrm{C}\right)\end{array}$ & $\mathrm{pH}$ & $\begin{array}{l}\text { Conductivity } \\
(\mu \mathrm{S} / \mathrm{cm})\end{array}$ & $\begin{array}{l}\text { Alkalinity } \\
(\mathrm{mg} / \mathrm{l})\end{array}$ & Hardness $\left.(\mathrm{mg} / \mathrm{lCaCO})_{3}\right)$ \\
\hline 0 & $4.74 \pm 0.27^{a}$ & $28.13 \pm 1.07^{a}$ & $6.78 \pm 0.28^{\mathrm{a}}$ & $166.07 \pm 2.04^{\mathrm{a}}$ & $37.41 \pm 0.45^{\mathrm{a}}$ & $39.32 \pm 0.8 \mathrm{I}^{\mathrm{a}}$ \\
\hline 60 & $4.29 \pm 0.23^{\mathrm{a}}$ & $27.53 \pm 1.18^{\mathrm{a}}$ & $6.64 \pm 0.29^{a}$ & $167.17 \pm 1.47^{a}$ & $37.91 \pm 0.49^{a}$ & $38.40 \pm 0.36^{a}$ \\
\hline 70 & $4.37 \pm 0.35^{\mathrm{a}}$ & $26.87 \pm 1.25^{\mathrm{a}}$ & $6.83 \pm 0.27^{\mathrm{a}}$ & $|66.5| \pm|.3|^{\mathrm{a}}$ & $38.18 \pm 1.96^{\mathrm{a}}$ & $37.61 \pm 0.58^{a}$ \\
\hline 80 & $4.48 \pm 0.12^{\mathrm{a}}$ & $27.37 \pm 0.78^{\mathrm{a}}$ & $6.79 \pm 0.4 \mathrm{I}^{\mathrm{a}}$ & $165.96 \pm 1.32^{\mathrm{a}}$ & $40.76 \pm 2.69^{a}$ & $38.33 \pm 0.54^{\mathrm{a}}$ \\
\hline 100 & $4.38 \pm 0.36^{\mathrm{a}}$ & $26.67 \pm 1.02^{\mathrm{a}}$ & $6.79 \pm 0.16^{\mathrm{a}}$ & $166.79 \pm 2.14^{\mathrm{a}}$ & $36.75 \pm 0.85^{a}$ & $38.72 \pm 0.83^{a}$ \\
\hline 120 & $4.38 \pm 0.38^{a}$ & $27.74 \pm 0.9 I^{\mathrm{a}}$ & $6.72 \pm 0.19^{a}$ & $167.23 \pm 2.50^{\mathrm{a}}$ & $38.67 \pm 1.05^{\mathrm{a}}$ & $38.26 \pm 0.33^{\mathrm{a}}$ \\
\hline 140 & $4.12 \pm 0.12^{\mathrm{a}}$ & $26.88 \pm 0.19^{a}$ & $6.77 \pm 0.22^{\mathrm{a}}$ & $|67.05 \pm 2.7|^{a}$ & $38.5 \mathrm{I} \pm 0.47^{\mathrm{a}}$ & $38.80 \pm 0.85^{a}$ \\
\hline
\end{tabular}

Mean with the same superscript under the same parameter are not significantly different at $\mathrm{p}<0.05$

Table 3 The mean time (min.) of induction and recovery of C. gariepinus fingerlings from clove powder anaesthetic

\begin{tabular}{|c|c|c|c|c|c|c|c|}
\hline \multirow{2}{*}{$\begin{array}{l}\text { Conc. } \\
\text { (mg/l) }\end{array}$} & \multicolumn{4}{|c|}{ Stages of induction(min) } & \multicolumn{3}{|c|}{ Stages of recovery(min) } \\
\hline & I & II & III & IV & I & II & III \\
\hline 60 & $7.73 \pm 0.24^{b}$ & $14.73 \pm 0.47^{a}$ & $0.00 \pm 0.00^{c}$ & $0.00 \pm 0.00^{c}$ & $0.00 \pm 00^{\mathrm{a}}$ & $0.00 \pm 0.00^{\mathrm{a}}$ & $0.00 \pm 0.00^{\mathrm{a}}$ \\
\hline 70 & $6.40 \pm 0.29 c$ & $9.13 \pm 0.43^{b}$ & $|2.07 \pm 0.4|^{\mathrm{a}}$ & $0.00 \pm 0.00^{\mathrm{d}}$ & $0.00 \pm 00^{\mathrm{a}}$ & $0.00 \pm 0.00^{\mathrm{a}}$ & $0.00 \pm 0.00^{\mathrm{a}}$ \\
\hline 80 & $3.60 \pm 0.20^{d}$ & $5.73 \pm 0.63^{c}$ & $8.53 \pm 0.63^{b}$ & II. $20 \pm 0.72^{\mathrm{a}}$ & $6.47 \pm 0.18^{b}$ & $5.20 \pm 0.73^{b}$ & $8.47 \pm 3.74^{\mathrm{a}}$ \\
\hline 100 & $2.60 \pm 0.20^{d}$ & $4.33 \pm 0.13^{c}$ & $5.73 \pm 0.18^{b}$ & $7.00 \pm 0.35^{\mathrm{a}}$ & $8.33 \pm 0.24^{b}$ & $8.60 \pm 0.35^{b}$ & $15.43 \pm 0.47^{\mathrm{a}}$ \\
\hline 120 & $1.00 \pm 0.00^{c}$ & $1.67 \pm 0.07^{c}$ & $2.73 \pm 0.24^{b}$ & $4.93 \pm 0.13^{\mathrm{a}}$ & $9.90 \pm 0.2 \mathrm{I}^{\mathrm{c}}$ & $13.03 \pm 0.94^{b}$ & $17.87 \pm .22^{\mathrm{a}}$ \\
\hline 140 & $0.00 \pm 0.00^{\mathrm{b}}$ & $0.20 \pm 0.1 \mathrm{I}^{\mathrm{b}}$ & $0.80 \pm 0.12^{b}$ & $2.13 \pm 0.67^{a}$ & $16.17 \pm 0.42^{c}$ & $19.46 \pm 1.18^{b}$ & $27.12 \pm 0.98^{a}$ \\
\hline
\end{tabular}

Means with the same superscript under each of the concentration are not significant $(P>0.05)$

Table 4 The mean time $(\min )$ of induction and recovery of $H$. bidorsalis fingerlings from clove powder anaesthetic

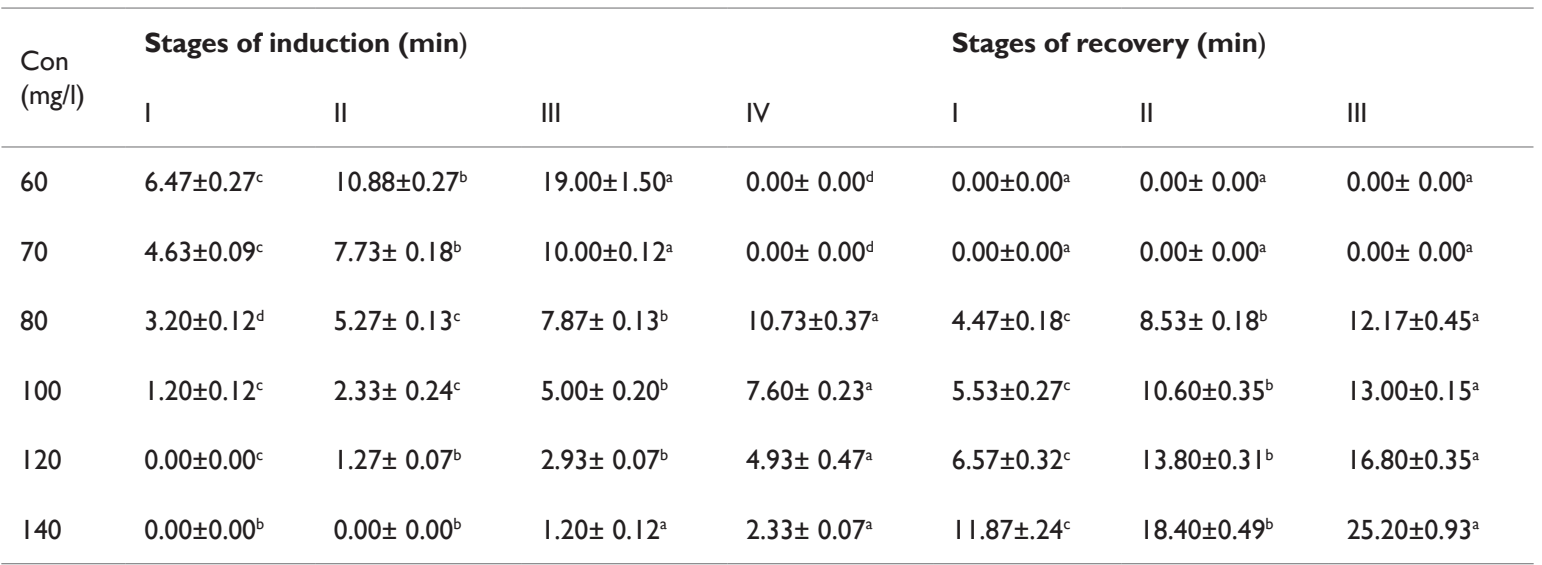

Means with the same superscript under each of the concentration are not significant $(P>0.05)$ 
The induction stages of the fingerlings at the various levels of concentrations were not significant $(\mathrm{P}>0.05)$ except at 60 and $100 \mathrm{mg} / \mathrm{l}$ where the time in C. gariepinus was higher (Table 5). The mean values of the various stages of induction and recovery showed that, stages 2, 4 (deep anaesthesia) and recovery stage 1 were significantly higher $(\mathrm{P}<0.05)$ in $C$. gariepinus. The mean time to regain complete equilibrium (recovery 3) in the both species was not significant $(\mathrm{P}>0.05)$ (Figure 1). The interaction of species and concentrations also had significant changes $(\mathrm{P}<0.01)$ on all the stages of induction and recovery except at induction stage 1 and recovery stage 3 , which was not significantly $(\mathrm{P}>0.05)$ different.

Table 5 Comparative mean values of various stages of induction and recovery of $C$. gariepinus and $H$. bidorsalis fingerlings on the various levels of clove powder

\begin{tabular}{|c|c|c|c|c|c|c|c|c|c|c|c|c|c|c|}
\hline \multirow{3}{*}{$\begin{array}{l}\text { Conc. } \\
\text { (mg/l) }\end{array}$} & \multicolumn{8}{|c|}{ Stage of induction ( $\mathrm{min}$ ) } & \multicolumn{6}{|c|}{ Stage of recovery $(\mathrm{min})$} \\
\hline & \multicolumn{2}{|l|}{ I } & \multicolumn{2}{|l|}{2} & \multicolumn{2}{|l|}{3} & \multicolumn{2}{|l|}{4} & \multicolumn{2}{|l|}{ I } & \multicolumn{2}{|l|}{2} & \multicolumn{2}{|l|}{3} \\
\hline & C.g & H.b & C.g & H.b & C.g & H.b & C.g & H.b & C.g & H.b & C.g & H.b & C.g & H.b \\
\hline 60 & $\begin{array}{l}7.73 \\
\pm 0.24^{\mathrm{a}}\end{array}$ & $\begin{array}{l}6.47 \\
\pm 0.27^{\mathrm{a}}\end{array}$ & $\begin{array}{l}14.73 \\
\pm 0.47^{\mathrm{a}}\end{array}$ & $\begin{array}{l}10.88 \\
\pm 0.27^{b}\end{array}$ & $\begin{array}{l}0.00 \\
\pm 0.00^{b}\end{array}$ & $\begin{array}{l}19.00 \\
\pm 1.50^{\mathrm{a}}\end{array}$ & $\begin{array}{l}0.00 \\
\pm 0.00^{\mathrm{a}}\end{array}$ & $\begin{array}{l}0.00 \\
\pm 0.00^{\mathrm{a}}\end{array}$ & $\begin{array}{l}0.00 \\
\pm 0.00^{\mathrm{a}}\end{array}$ & $\begin{array}{l}0.00 \\
\pm 0.00^{\mathrm{a}}\end{array}$ & $\begin{array}{l}0.00 \\
\pm 0.00^{\mathrm{a}}\end{array}$ & $\begin{array}{l}0.00 \\
\pm 0.00^{\mathrm{a}}\end{array}$ & $\begin{array}{l}0.00 \\
\pm 0.00^{\mathrm{a}}\end{array}$ & $\begin{array}{l}0.00 \\
\pm 0.00^{\mathrm{a}}\end{array}$ \\
\hline 70 & $\begin{array}{l}6.40 \\
\pm 0.29^{a}\end{array}$ & $\begin{array}{l}4.63 \\
\pm 0.09^{a}\end{array}$ & $\begin{array}{l}9.13 \\
\pm 0.43^{a}\end{array}$ & $\begin{array}{l}7.73 \\
\pm 0.18^{\mathrm{b}}\end{array}$ & $\begin{array}{l}12.07 \\
\pm\left. 0.4\right|^{a}\end{array}$ & $\begin{array}{l}10.00 \\
\pm 0.12^{\mathrm{a}}\end{array}$ & $\begin{array}{l}0.00 \\
\pm 0.00^{\mathrm{a}}\end{array}$ & $\begin{array}{l}0.00 \\
\pm 0.00^{\mathrm{a}}\end{array}$ & $\begin{array}{l}0.00 \\
\pm 0.00^{\mathrm{a}}\end{array}$ & $\begin{array}{l}0.00 \\
\pm 0.00^{\mathrm{a}}\end{array}$ & $\begin{array}{l}0.00 \\
\pm 0.00^{\mathrm{a}}\end{array}$ & $\begin{array}{l}0.00 \\
\pm 0.00^{\mathrm{a}}\end{array}$ & $\begin{array}{l}0.00 \\
\pm 0.00^{\mathrm{a}}\end{array}$ & $\begin{array}{l}0.00 \\
\pm 0.00^{2}\end{array}$ \\
\hline 80 & $\begin{array}{l}3.60 \\
\pm 0.20^{\mathrm{a}}\end{array}$ & $\begin{array}{l}3.20 \\
\pm 0.12^{\mathrm{a}}\end{array}$ & $\begin{array}{l}5.73 \\
\pm 0.63^{\mathrm{a}}\end{array}$ & $\begin{array}{l}5.27 \\
\pm 0.13^{\mathrm{a}}\end{array}$ & $\begin{array}{l}8.53 \\
\pm 0.63^{\mathrm{a}}\end{array}$ & $\begin{array}{l}7.87 \\
\pm 0.13^{\mathrm{a}}\end{array}$ & $\begin{array}{l}11.20 \\
\pm 0.72^{\mathrm{a}}\end{array}$ & $\begin{array}{l}10.73 \\
\pm 0.37^{\mathrm{a}}\end{array}$ & $\begin{array}{l}6.47 \\
\pm 0.18^{\mathrm{a}}\end{array}$ & $\begin{array}{l}4.47 \\
\pm 0.18^{\mathrm{a}}\end{array}$ & $\begin{array}{l}4.20 \\
\pm 0.73^{\mathrm{b}}\end{array}$ & $\begin{array}{l}8.53 \\
\pm 0.18^{a}\end{array}$ & $\begin{array}{l}8.47 \\
\pm 3.74^{b}\end{array}$ & $\begin{array}{l}12.17 \\
\pm 0.45^{a}\end{array}$ \\
\hline 100 & $\begin{array}{l}2.60 \\
\pm 0.20^{\mathrm{a}}\end{array}$ & $\begin{array}{l}1.20 \\
\pm 0.12^{\mathrm{a}}\end{array}$ & $\begin{array}{l}4.33 \\
\pm 0.13^{\mathrm{a}}\end{array}$ & $\begin{array}{l}2.33 \\
\pm 0.24^{b}\end{array}$ & $\begin{array}{l}5.73 \\
\pm 0.18^{a}\end{array}$ & $\begin{array}{l}5.00 \\
\pm 0.20^{\mathrm{a}}\end{array}$ & $\begin{array}{l}7.00 \\
\pm 0.35^{\mathrm{a}}\end{array}$ & $\begin{array}{l}7.60 \\
\pm 0.23^{\mathrm{a}}\end{array}$ & $\begin{array}{l}8.33 \\
\pm 0.24^{\mathrm{a}}\end{array}$ & $\begin{array}{l}5.53 \\
\pm 0.27^{b}\end{array}$ & $\begin{array}{l}8.60 \\
\pm 0.35^{b}\end{array}$ & $\begin{array}{l}10.60 \\
\pm 0.35^{\mathrm{a}}\end{array}$ & $\begin{array}{l}15.43 \\
\pm 0.47^{\mathrm{a}}\end{array}$ & $\begin{array}{l}13.00 \\
\pm 0.15^{\circ}\end{array}$ \\
\hline 120 & $\begin{array}{l}1.00 \\
\pm 0.00^{\mathrm{a}}\end{array}$ & $\begin{array}{l}0.00 \\
\pm 0.00^{\mathrm{a}}\end{array}$ & $\begin{array}{l}1.67 \\
\pm 0.07^{a}\end{array}$ & $\begin{array}{l}1.27 \\
\pm 0.07^{\mathrm{a}}\end{array}$ & $\begin{array}{l}2.73 \\
\pm 0.24^{a}\end{array}$ & $\begin{array}{l}2.93 \\
\pm 0.07^{\mathrm{a}}\end{array}$ & $\begin{array}{l}4.93 \\
\pm 0.13^{\mathrm{a}}\end{array}$ & $\begin{array}{l}4.93 \\
\pm 0.47^{\mathrm{a}}\end{array}$ & $\begin{array}{l}9.90 \\
\pm\left. 0.2\right|^{\mathrm{a}}\end{array}$ & $\begin{array}{l}6.57 \\
\pm 0.32^{b}\end{array}$ & $\begin{array}{l}13.03 \\
\pm 0.94^{\mathrm{a}}\end{array}$ & $\begin{array}{l}13.80 \\
\pm\left. 0.3\right|^{\mathrm{a}}\end{array}$ & $\begin{array}{l}17.87 \\
\pm 0.22^{\mathrm{a}}\end{array}$ & $\begin{array}{l}16.80 \\
\pm 0.35^{\mathrm{a}}\end{array}$ \\
\hline 140 & $\begin{array}{l}0.00 \\
\pm 0.00^{\mathrm{a}}\end{array}$ & $\begin{array}{l}0.00 \\
\pm 0.00^{\mathrm{a}}\end{array}$ & $\begin{array}{l}0.20 \\
\pm 0.1 \mathrm{I}^{\mathrm{a}}\end{array}$ & $\begin{array}{l}0.00 \\
\pm 0.00^{\mathrm{a}}\end{array}$ & $\begin{array}{l}0.80 \\
\pm 0.12^{b}\end{array}$ & $\begin{array}{l}1.20 \\
\pm 0.12^{\mathrm{a}}\end{array}$ & $\begin{array}{l}2.13 \\
\pm 0.67^{\mathrm{a}}\end{array}$ & $\begin{array}{l}2.33 \\
\pm 0.07^{\mathrm{a}}\end{array}$ & $\begin{array}{l}16.17 \\
\pm 0.42^{\mathrm{a}}\end{array}$ & $\begin{array}{l}11.87 \\
\pm .24^{\mathrm{a}}\end{array}$ & $\begin{array}{l}19.46 \\
\pm 1.18^{\mathrm{a}}\end{array}$ & $\begin{array}{l}18.40 \\
\pm 0.49^{\mathrm{a}}\end{array}$ & $\begin{array}{l}27.12 \\
\pm 0.98^{a}\end{array}$ & $\begin{array}{l}25.20 \\
\pm 0.93^{\mathrm{a}}\end{array}$ \\
\hline
\end{tabular}

Means with the same superscript under each of the variables are not significant $(P>0.05)$, C. gariepinus $(C . g), H$. bidorsalis $(H . b)$

$$
\text { 田C.gariepinus } \mathbf{0} \text { H. bidorsalis }
$$

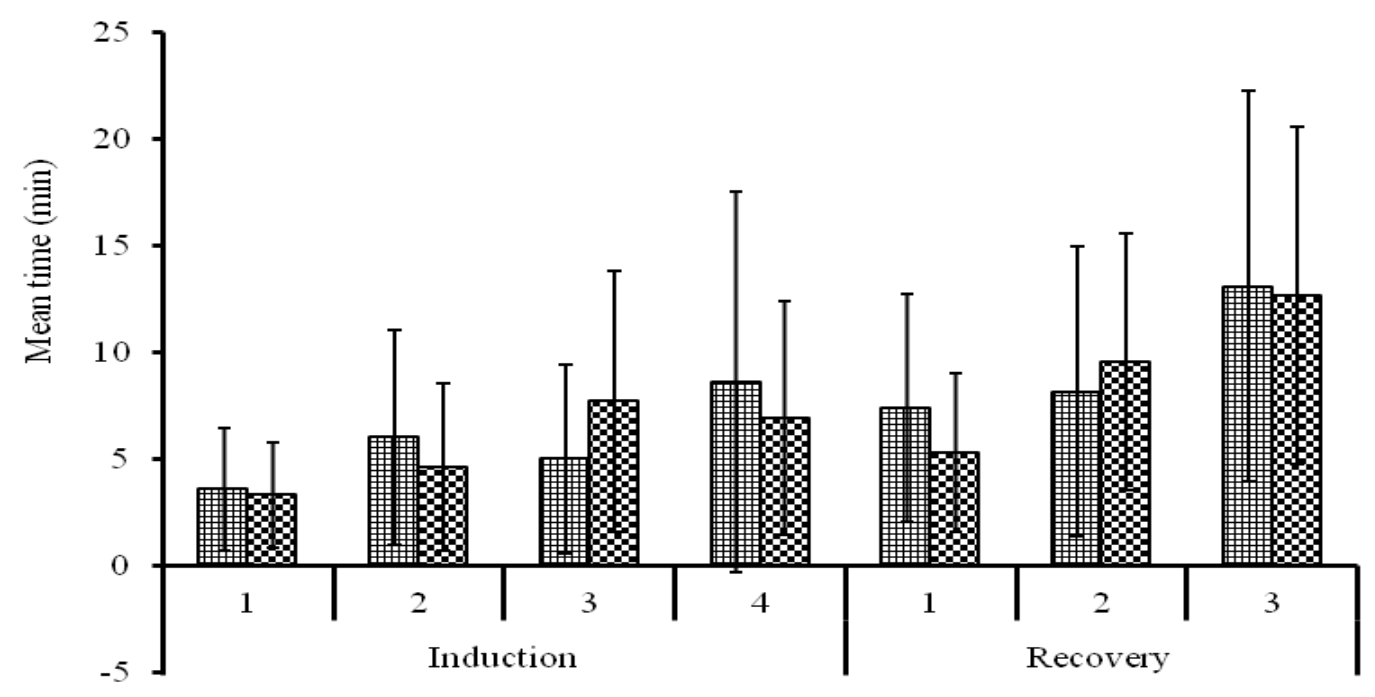

Stage (Induction and Recovery)

Figure I Comparism of the various stages of induction and recovery time (min.) of C.gariepinus and $H$. bidosarlis fingerlings exposed to clove powder anaesthetic for 30 min. Bars $\pm S . D$ Mean with different letters differs significantly $(P<0.05 ; H S D)$. 


\section{Discussion}

The water quality parameter of the various test media did not vary significantly $(\mathrm{P}<0.05)$ from those of the control. Since the parameters examined were within acceptable ranges for toxicity test ${ }^{24,27}$ they may not have acted synergistically with the anaesthesia to affect the behavior observed during the research. The result from this study compares favourably with those conducted to compare the efficacy of commonly used anaesthetics on various fishes. ${ }^{28-31}$ Hamackova et al., ${ }^{32}$ and Sudagara et al., ${ }^{16}$ previously reported the sedative, anaesthesia and myorelant effect of clove active ingredient eugenol in various European and Asian fishes, therefore the anaesthetics effect of this clove powder on African clariids in this study was not unexpected. Eugenol (active ingredient of clove plant), have also been reported to be extremely safer for human when consumed as food additive but which was toxic to some fish species in prolong exposure. ${ }^{33-35}$ The current study to determine the anaesthetics efficacy of clove powder on the African catfishes fingerlings observed series of behaviours manifested by the exposed fish to include, acceleration of opercular movements, partial loss of reaction to external stimuli and loss of equilibrium, which may be due to the anaesthetic effect of clove powder on the central nervous system (CNS). Various workers reported similar responses of fishes to anaesthetics such as Hajek et al., ${ }^{36}$ on common carp, Homackova et al., ${ }^{32}$ on Tinca tinca, Sudagara et al., ${ }^{16}$ on Rutilus rutilus, Zaikov et al., ${ }^{37}$ on pike and Okey et al., ${ }^{21}$ on African catfish hybrid. The progression through these various stages of anaesthasia was consistent with the descriptions by Keene et al., ${ }^{14}$ Zaikov et al. ${ }^{37}$ and Hikasa et al. ${ }^{38}$ According to Summerfelt et al., ${ }^{3}$ anaesthetic act on the Central nervous system (CNS) and induces calming effect, loss of equilibrium, mobility, consciousness and finally loss of reflex action in an organism exposed to higher concentrations. Ross \& Ross ${ }^{5}$ reported that anaesthesia is achieved by placing the fish into an anaesthetic solution that is absorbed through the gills and enter the arterial blood to the central nervous system. Anaesthetics are needed for easy handling, sorting, measuring, transporting and surgical procedures in aquaculture and fisheries to facilitate application procedure. Generally, an ideal anaesthetic ought to induce anesthesia quickly in less than $6 \mathrm{~min}$, permit a fast recovery in $10 \mathrm{~min}$ or less, not poisonous to fish and hazardous to human and be inexpensive. ${ }^{4}$ In this study, $80 \mathrm{mg} / 1$ to $140 \mathrm{mg} / 1$ were required to induce deep anaesthesia (stage 4) in more than 2 mins. However, rapid anaesthesia (less than 4 and 3 mins) was induced with higher concentrations 120 and $140 \mathrm{mg} / 1$ respectively. This is an indication that the time of induction (anaesthesia) is concentration dependent that is the higher the concentration the lower the time to be completely immobilized and the higher the time of recovery. This trend may reflect the degree of the anaesthetic delivered to the CNS, indicating that the higher the concentration, the faster the anaesthetic is absorbed and delivered to the CNS with duration of exposure. Sudagara et al., ${ }^{16}$ found that $225-350 \mathrm{mg} / 1$ of clove powder solution was required to completely immobilized (Stage 4) roach Rutilus rutilus in less than $(<4 \mathrm{~min})$ of exposure and Velisek et al., ${ }^{10}$ also reported the similar time with $80 \mathrm{mg} / 1$ of clove oil on European catfish (Silurus glanis L) juveniles. Other workers who used clove oil at $80 \mathrm{mg} / 1$ to achieved deep anaesthesia within the duration $(<4 \mathrm{mins})$ described clove effective and safe. ${ }^{39,40}$ In this study induction time of less 4 mins was recorded for the various clariids at concentrations between $80-140 \mathrm{mg} / \mathrm{l}$, meaning that clove powder is also effective and safe for the clarrids. Valuable induction time of 2-8mins were also reported for various fish species in $30-80 \mathrm{mg} / 1$ clove oil on $O$. mykiss ${ }^{41}$
O. tshawytscha, ${ }^{42}$ Piaractus brachipomus, ${ }^{29}$ Brycon amazonicus ${ }^{43}$ and $S$. salar ${ }^{44}$. However, in this study the effective concentration that induced anaesthsia without mortality were within $80-140 \mathrm{mg} / 1$. Although crude clove powder was used in this study, the effective concentrations were within the recommended $(25-120 \mathrm{mg} / \mathrm{l})$ for clove oil. Hikasa et al. ${ }^{38}$ recommended $25-100 \mathrm{ppm}$ clove oil as effective anaesthesia for the common carp (C. carpio) and Small ${ }^{45}$ reported $100 \mathrm{mg} / \mathrm{l}$ clove oil as a safe concentration for anaesthesia of the channel catfish (Ictalurus punctatus), adding that exposures longer than 15 mins prolonged recovery time and may cause mortality. Walsh and Pease ${ }^{46}$ recommended $60-80 \mathrm{mg} / 1$ clove oil for anaesthesia of anguillid eels (Anguilla reinhardti) because it is effective, relatively inexpensive, and poses little risk to human health. Adebayo et al., ${ }^{13}$ reported that aqueous extracts of avocado pear leaf at concentrations within 130-190ml/1 induced anaesthesia on C. gariepinus bloodstock, with efficacy between 130 and $190 \mathrm{ml} / 1$, effective concentration of $190 \mathrm{ml} / 1$ and a recovery time of $12 \mathrm{~min}$.

The time to recover from anaesthesia is dependent on concentration and induction time. ${ }^{38}$ The higher the concentration, the lower the time of induction (anaesthesia) and the longer the recovery time. Similar observation was also recorded in this study. For instance, (less than 9mins) and (more than 27mins) were required for fingerlings of the clarrids to regain full recovery at $80 \mathrm{mg} / 1$ and $140 \mathrm{mg} / 1$ of clove powder respectively. The recovery time was shorter when lower concentrations of the clove powder were used. These observations followed the same pattern as those described for clove oil by Hamackova et al., ${ }^{32}$ in tench (Tinca tinca), Velisek et al. ${ }^{40}$ in common carp (C. carpio) and Okey et al. ${ }^{21}$ in Afircan catfish hybrid. When the concentration of clove powder was increased, the time to loosing equilibrium, as well as reaching stage 4 (complete immobilization) declines. Other authors using clove oil anaesthesia on different fish species such as Keene et al.. ${ }^{41}$ Hoskonen and Pirhonen, ${ }^{47}$ Zaikov et al., ${ }^{37}$ established similar inverse proportional dependencies between recovery time and concentrations. However, the time to regain full recovery from anaesthesia induced by clove powder on the fingerlings varies with the species. The fingerlings of $C$. gariepinus at $140 \mathrm{mg} / \mathrm{l}$ achieved deep anaesthesia in $2.13 \mathrm{~min}$ and recover at $27.12 \mathrm{~min}$ whereas $H$. bidorsalis had the same induction time $(2.33 \mathrm{~min})$, but a lower recovery time of $25.20 \mathrm{~min}$. similar result was demonstrated by Soto and Burhanuddin ${ }^{48}$ and Anderson et al. ${ }^{49}$ who used clove oil $(33-120 \mathrm{mg} / 1)$ and reported recovery time of $150 \mathrm{sec}$ for Siganus lineatus and $190 \mathrm{sec}$ for rainbow trout respectively. Several studies involving the clarrids confirm the above observation. ${ }^{13,50}$

Studies involving other botanicals used as anaesthetics show that clariid had higher recovery time under clove powder anaesthesia than others which according to Keene et $a{ }^{4}{ }^{41}$ is needed for prolong surgical manipulation of the fish. According to Adebayo et al. ${ }^{13}$, the effective concentration of avocado pear leaf extracts that completely anaesthetized C. gariepinus broodstooks was $190 \mathrm{ml} / 1$ with a recovery time of 12 mins. Ayuba and Ofejukwu ${ }^{50}$ reported that $C$. gariepinus fingerlings were anaesthetized in $10 \mathrm{~min}$ and recovers within $2 \mathrm{~min}$ of immersion in freshwater after exposure to $2.0 \mathrm{~g} / 1$ of dried seed extract of toloache plant, D. innoxia. The essential oil of $L$. alba was used at concentrations of 100 to $500 \mathrm{mg} / 1$ to induce anaesthesia (Stage 4) in silver catfish in 3-6mins and recover within 6-12mins. ${ }^{51}$ Menthol, the main component of the essential oil of plants from genus Mentha, at concentrations of $100-200 \mathrm{mg} / \mathrm{l}$ induced deep anaesthesia in tambaqui after $1-2 \mathrm{~min}$ and with recovery time of $5-12 \mathrm{~min}^{52}$ The recovery time recorded for clarrids in this study were slightly higher than those 
recommended for some European and Asian fishes. This implies that some water quality especially temperature can affect the rate of biodegradation and excretion of the toxicant from the blood streams via the gills hence affecting the recovery time.

Physiological responses in fish to anaesthetics are different. Kucuk $^{2}$ reported that the gills area, body weight, species and metabolic rate have effects on the rate of anaesthetics absorption and induction (anaesthesia). This may have accounted for the slight differences in the induction and recovery time in the various species of clariids recorded in this study. Generally, an ideal anaesthetic ought to induce anesthesia quickly in less than $3 \mathrm{~min}$, permit a fast recovery in $5 \mathrm{~min}$ or less, produce no poison to fish, cause no hazard to human and be inexpensive. ${ }^{4}$ The result from this study indicated that clove powder at the concentrations of $80-140 \mathrm{mg} / 1$ induced deep anaesthesia between 3-10min. with a recovery time of between 8-27mins making it an ideal anaesthetic for clariids. However, quick induction and a slightly longer recovery time would allow for varied manipulations as desirable, hence clove powder is an ideal anaesthetics for the African clarrid fingerlings.

\section{Acknowledgements}

We express sincere thanks to the Head Department of Fisheries Aquatic Science, CRUTECH and staff of RSUST for providing the necessary facilities, suggestions and guidance toward the accomplishment of this research.

\section{Conflict of interest}

The author declares that there is no conflict of interest.

\section{References}

1. Barton BA. Stress. In: Stickney RR, editors. Encyclopedia of Aquaculture. John Wiley and Sons, New York, 2000. p. 892-898.

2. Küçük S. Efficacy of tricaine on Peocilia latipinna at different temperatures and concentrations. African Journal of Biotechnology. 2010;9(5):755-759.

3. Summerfelt RC, Smith LS. Anaesthesia, surgery, and related techniques. In: Schreck CB, Moyle PB, editors. Methods for Fish Biology. American Fisheries Society, Bethesda. 1990;213-272.

4. Mylonas CC, Cardinaletti G, Sigelaki I, et al. Comparative efficacy of Clove oil and 2-phenoxyethanol as anaesthetics in the aquaculture of European sea bass (Dicentrarchus labrax) and gilthead sea bream (Sparus aurata) at different temperatures. Aquaculture. 2005;246(14):467-481.

5. Ross LG, Ross B. Anaesthetic and Sedative Techniques for Aquatic Animals. 2nd ed. Blackwell, London. 1999; 233 p.

6. Coyle SD, Durborow RM, Tidwell JH (2004) Anaesthetics in Aquaculture. SRAC publication, Texas. 6 p.

7. Woody CA, Nelson J, Ramstad K. Clove oil as an anaesthetic for adult sockeye salmon: field trails. Journal of Fish Biology. 2004;60:340-347.

8. Markings LL, Meyer FP. Are better anaesthetics needed in fisheries? Fisheries. 1985;10(6):2-5.

9. Yanar M, Kumlu M. The Anaesthetics Effects of Quinaldine Sulphate and/or Diazepam on Sea Bass (Dicentrarchus labrax) Juveniles. Turkish Journal of Veterinary and Animal Science. 2000;25:185-189.

10. Velisek J, Wlasow T, Gomulka P, et al. Effects of Clove Oil anaesthesia on European catfish (Silurus glanis). Acta Veterinaria Brno. 2006;75(1):99106.
11. Mgbenka BO, Ejiofor EN. Effect of extract of dried leaves of Erythrophleum suaveolens as anaesthetics on Clariid Catfish. Journal of Applied Aquaculture. 1998;8(4):73-80.

12. Agokei OE, Adebisi AA. Tobacco as an anaesthetic for fish handling procedures. Journal of Medicinal Plants Research. 2010; 4(14):13961399.

13. Adebayo TO, Fasakin EA, Popoola OM. Use of Aqueous Extracts of Avocado Pear, Pyrus Communis, Leaf as Anaesthetic in Gonadectomy of African Catfish, Clarias gariepinus. Journal of Applied Aquaculture. 2010;22(2):117-122

14. King W, Hooper B, Hillsgrove S, et al. The use of Clove oil, metomidate, tricaine methanesulphonate and 2-phenoxyethanol for inducing anaesthesia and their effect on the cortisol stress response in black sea bass (Centropristis striata L.). Aquaculture Resources. 2005;36(14):1442-1449.

15. Velisek J, Svobodova Z, Piackova V. Effects of 2-Phenoxyethanol Anaesthesia on Haematological Profile on Common Carp (Cyprinus carpio) and Rainbow Trout (Oncorhynchus mykiss). Acta Veterinaria Brno. 2007;76(3):487-492.

16. Sudagara M, Mohammadizarejabada A, Mazandarania R, et al. The efficacy of Clove powder as an anaesthetic and its effect on hematological parameters on Roach (Rutilus rutilus). Journal of Aquaculture feed science and nutrition. 2009;1(1):1-5.

17. Chaieb K, Hajlaoui H, Zmantar T. The chemical composition and biological activity of Clove essential oil, Eugenia caryophyllata (Syzigium aromaticum L. Myrtaceae): A short review. Phytother Res. 2007;21(6):501-6.

18. Abiola B. Herbal help Clove. In Health and fitness. Indulge magazine. 2008; $59 \mathrm{p}$.

19. Awachie JBE, Ezenwaji HMG. The Importance of Clarias species in the Fishery Development of Anambra River Basin. CIFA Technical Paper. 1998;212-224.

20. Okey B, Keremah RI, Ofem BO. Effect of Clove (Eugenia aromatica) powder anaesthetic on some haematological parameters in hybrid catfish (Heterobranchus bidorsalis $9 x$ Clarias gariepinus ${ }^{\lambda}$ ) juveniles. International Journal of Fisheries and Aquaculture, 2013;5(7):184-192.

21. Bell G. An outline of anaesthetic and anaesthesia for salmonids, a guide for $\phi$ sh culturists in British Columbia. Canadian Technical Report of Fisheries and Aquatic Sciences, 1987; 534, 16p.

22. Iwama GK, McGeer JC, Pawluk MP. The effects of five fish anaesthetics on acid-base balance, hematocrit, cortisol and adrenaline in rainbow trout. Canadian Journal of Zoology, 1989;67(8):2065-2073.

23. APHA. Standard methods for the examination of water and waste water 17th edn. America Public Health Association, Washington. 1998; 1189p.

24. Zar JH. Biostatistical Analysis. 4th Edn Prentice Hall. New Jersey. 1999; $468 \mathrm{p}$

25. Wahua TAT. Applied statistics for scientific studies. Afrika Link Books. Aba, Nigeria. 1999; 365 p.

26. Adeniji HA, Ovie SL. A simple guide to water quality management in fish ponds. National Institute of Fresh water Fisheries Research. Technical paper. 1989;23:21-34.

27. Hseu JR, Yeh SL, Chu YT, et al. Comparison of efficacy of five anaesthetics in goldlined sea bream, Sparus sarba. Acta Zoological of Taiwan.1998;9(1):35-41.

28. Sladky KK, Swanson CR, Stoskopt MK, et al. Comparative efficacy of tricaine methanesulfonate and Clove oil for use as anaesthetics in red pacu (Piaractus brachypomus). American Journal of Veterinary Research. 2001;62(3):337-342. 
29. Tsantilas H, Galatos AD, Athanassopoulou F, et al. Efficacy of 2-phenoxyethanol as an anaesthetic for two size classes of white sea bream, Diplodus sargus L. and sharp snout sea bream, Diplodus puntazzo. Aquaculture. 2006;253(1-4):64-70.

30. Velisek J, Svobodova Z, Piackova V, et al. Effects of Clove oil anaesthesia on common carp (Cyprinus carpio L.). Veterinaria Medicinae of Czech. 2005b; 50(6):269-275.

31. Hamackova J, Sedova JM, Pjanova SV, et al. The effect 2-phenoxyethanol, Clove oil and Propiscin anaesthetics on perch (Perca fluviatilis) in relation to water temperature. Czech. Journal of Animal Science. 2006;46:469-473.

32. Maura A, Pino A, Ricci R. Negative evidence in vivo of DNA-damaging, mutagenic and chromosomal effects of eugenol. Mutation Research. 1989;227(2):125-129.

33. Curtis EK. In pursuit of palliation: oil of Cloves in the art of dentistry. Bulletin of Histologist and Dentist. 1990;38, 9-14.

34. Hussein MM, Wada S, Hatai K, et al. Antimycotic activity of eugenol against selected water molds. Journal of Aquatic Animal Health. 2000;12(3):224-229.

35. Hajek GJ, Kyszejko B, Dziaman R. The anaesthetic effect of Clove oi on common carp, Cyprinus carpio L. Acta Ichthyologica et Piscatoria. 2006;36(2):93-97.

36. Zaikov A, Ilielv F, Hubenova T. Induction and recovery from anaessthesia in pike (Esox lucius L.) exposed to Clove oil. Bulgarian Journal of Agricultural Science. 2008;14(2):165-170.

37. Hikasa Y, Katsuaki T, Ogasawara T, et al. Anaesthesia and recovery with tricaine methanesulfonate, eugenol, and thiopental sodium in the carp, Cyprinus carpio. Japanese Journal of Veterinary Research. 1986;48(2):341-351.

38. Prince A, Powell C. Clove oil as an anaesthetic for invasive field procedures on adult rainbow trout. North American Journal of Fisheries Management. 2000;20(4):1029-1032.

39. Velisek J, Svobodova Z, Piaakova V. Effects of Clove Oil Anaesthesia on Rainbow Trout (Oncorhynchus mykiss). Acta Veterinaria Brno. 2005;74(1):139-146.

40. Keene JL, Noakes DLG, Moccia RD, et al. The efficacy of Clove oil as an anaesthetic for rainbow trout Oncorhynchus mykiss. Aquaculture Research. 1998;29:89-101.
41. Cho GK, Heath DD. Comparison of tricaine methane sulphonate (MS222) and Clove oil anaesthesia effects on the physiology of juvenile Chinook salmon Oncorhynchus tshawytscha (Walbaum). Aquaculture Resources. 2000;31:537-546.

42. Inoue LAK, Santos NC, Moraes G. Clove oil as anaesthetic for juveniles of matrinxã Brycon cephalus (Gunther, 1869), Ciência Rural. 2005;33:943-947.

43. Iversen M, Finstad B, McKinlay RS, et al. The efficacy of metomidate, Clove oil, AQUI-STM and Benzoak1 as anaesthetics in Atlantic salmon (Salmo salar L.) smolts, and their potential stress-reducing capacity. Aquaculture. 2003;221:549-566.

44. Small BC. Anaesthetic effecacy of metomidate and comparison of plasma cortisol responses to tricaine methanesulfonate, quinaldine and Clove oil anethesized channel catesh Ictalurus punctatus. Aquaculture. 2003;218:177-185

45. Walsh CC, Pease RC. The Use of Clove Oil as anesthesia for longfin eel, Anguilla reinliditltii (Steindachner). Aquaculture Research. 2002;33:627-635.

46. Hoskonen P, J Pirhonen, Effects of some physiological indicators of anaesthetized fish, Oncorhynchus mykiss (Walbaum). Aquaculture Resources. 2006;37:409-415.

47. Soto CG, Burhanuddin F. Clove oil as a fish anaesthetic for measuring length and weight of rabbitfish (Siganus lineatus). Aquaculture. 1995;136(1-2):149-152.

48. Anderson GW, McKinley SR, Colavecchia M. The use of Clove oil as an anaesthetic for rainbow trout and its effects on swimming performance. North American Journal of Fisheries Management. 1997;17(2):301-307.

49. Ayuba VO, Ofojekwu PC. Acute toxicity of the root extract of Jimson's weeds Datura innoxia to the African catfish, $C$. gariepinus fingerlings. Journal of Aquatic Sciences. 2002;17(2):131-136.

50. Da Cunha MA, de Barros FMC, Garcia LO, et al. Essential oil of Lippia alba: A new anaesthetic for silver catfish, Rhamdia quelen. Aquaculture. 2010;306(1-4):403-406

51. Façanha MF, Gomes LC. A eficácia do mentol como anestésico para tambaqui (Colossoma macropomum, Characiformes: Characidae), Acta Amazonica. 2005;35(1):71-75. 